\title{
CEO emotional bias and investment decision, Bayesian network method
}

\author{
Mohamed Ali Azouzi* and Jarboui Anis
}

PhD student in Finance and Accounting Methods, Faculty of Management Sfax-Tunisia

\begin{tabular}{|c|c|}
\hline ART I CLE I NFO & AB S T R A C T \\
\hline $\begin{array}{l}\text { Article history: } \\
\text { Received October 1, } 2011 \\
\text { Received in Revised form } \\
\text { November, 14, } 2011 \\
\text { Accepted 15 February } 2012 \\
\text { Available online } \\
23 \text { February } 2012 \\
\text { Keywords: } \\
\text { Emotional bias } \\
\text { Corporate finance } \\
\text { Optimism } \\
\text { Overconfidence } \\
\text { Loss aversion } \\
\text { Capital investment decision } \\
\text { Bayesian network }\end{array}$ & $\begin{array}{l}\text { This research examines the determinants of firms' investment introducing a behavioral } \\
\text { perspective that has received little attention in corporate finance literature. The following } \\
\text { central hypothesis emerges from a set of recently developed theories: Investment decisions are } \\
\text { influenced not only by their fundamentals but also depend on some other factors. One } \\
\text { factor is the biasness of any CEO to their investment, biasness depends on the cognition and } \\
\text { emotions, because some leaders use them as heuristic for the investment decision instead of } \\
\text { fundamentals. This paper shows how CEO emotional bias (optimism, loss aversion and } \\
\text { overconfidence) affects the investment decisions. The proposed model of this paper uses } \\
\text { Bayesian Network Method to examine this relationship. Emotional bias has been measured by } \\
\text { means of a questionnaire comprising several items. As for the selected sample, it has been } \\
\text { composed of some } 100 \text { Tunisian executives. Our results have revealed that the behavioral } \\
\text { analysis of investment decision implies leader affected by behavioral biases (optimism, loss } \\
\text { aversion, and overconfidence) adjusts its investment choices based on their ability to assess } \\
\text { alternatives (optimism and overconfidence) and risk perception (loss aversion) to create of } \\
\text { shareholder value and ensure its place at the head of the management team. }\end{array}$ \\
\hline
\end{tabular}

(C) 2012 Growing Science Ltd. All rights reserved.

\section{Introduction}

Recently, the literature in behavioural finance departs from the traditional financial model to incorporate psychological evidence on non-standard preferences and beliefs, such as loss aversion, optimism, or overconfidence. This approach examines the consequences of CEO behavioral biases such as loss aversion, optimism,overconfidence, etc. traits that have been shown to be prevalent in managers. The studies act for managers decision making contain distortion of CEO financial decision (Hawkins et al., 2001; Ho \& Chang, 2009 ; Backer et al., 2004 ; Malmendier et al., 2010 ; Hackbarth, 2009 ; etc.). As for the investment decisions specifically, Heaton (2002) shows that CEO optimism distorted investment policy, in forms of either underinvestment or overinvestment, without invoking the traditional theories of agency and information asymmetry.

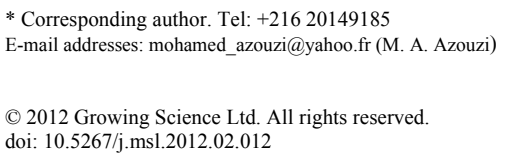


Several, empirical studies have found that CEO personal characteristics, particularly the CEO overconfidence may lead to distortions in corporate investment decision and that optimistic managers show significantly higher investment sensitivity to free cash flow, particularly for equity-dependent firms (Malmendier \& Tate, 2005), or for more financing constrained firms (Lin et al., 2005). Recent studies also document that CEO overconfident prefer internal finance over debt and for debt over equity (Malmendier et al., 2007). All of the above mentioned approaches hold in common one important point, namely, the implicit assumption that financial market participants as well as company managers always act rationally. However, an extensive and growing literature on human psychology and behavior shows that most people, including investors and managers, are subject to important limits in their cognitive processes and tend to develop behavioral biases that can significantly influence their decisions. Indeed, individual reasons are cognitive shortcuts that influence the position, making irrational and non-optimal in terms of traditional financial theories. These biases have been identified and classified and grouped as follows: The means of representation, reasoning analog bias of conservatism and confirmation, but also emotions such as loss aversion, optimism and the overconfidence.

This study examines the possible influence of three closely related emotional biases, which are extensively documented in behavioral research, loss aversion, optimism and overconfidence, on a firm's investment decisions. Recent theoretical Behavioral Corporate Finance literature suggests that these biases can substantially influence the investment and financing decisions made by business managers. In fact, one strong prediction emerges from this body of theories: optimistic and/or overconfident (or, for short, "biased") managers will choose higher leverage ratios for their firms than they would if they were "rational" (or not biased). Therefore, these biases could rank among the determinants of investment decision. This study offers one of the first empirical tests of this hypothesis and, at the same time, presents new evidence about the factors that better explain observed underinvestment or overinvestment, using a sample of Tunisian companies.

The article is structured as follows: Section 2 presents the related literature and the theories which motivate the empirical work and Section 3 discusses the empirical strategies that were adopted. Section 4 discusses the main results and Section 5 presents the concluding remarks.

\section{Hypothesis development}

The implications of managerial characteristics for corporate decisions have only recently begun to be explored by Behavioral Finance researchers. Some studies address the issue from the perspective of rational managers interacting with overconfident outside investors. Only recently has a smaller number of analyses emerged focusing the cognitive biases (optimism, overconfidence and loss aversion) of the managers themselves and trying to understand how they can affect their investment and financing decisions. Recently, Felton and al (2003), Gibson and Sanbonmatsu (2004) justify risky investment decisions by the leaders optimism level likely to seek information and their desire to solve a given problem without considering the success of previous projects. Schrand and Zechman (2009) show that overconfident managers make optimistic forecasts and in order to meet these forecasts, exhibit higher levels of fraud and earnings management. Ben-David and al (2007) use show that personal overconfidence causes managers to miscalibrate their expectations of future returns. In an influential series of studies Malmendier and Tate $(2005,2008)$ and Malmendier and al (2007, 2010) formalize the notion of overconfidence and provide empirical evidence of the effects of CEO overconfidence on capital investment and capital structure preferences.

We investigate the influence of managerial bias (loss aversion, optimism and overconfidence) about corporate investment choice.

Optimism and investment decision 
The role of managerial optimism in a firm's investment and financing decisions has been a subject of an ongoing debate in the corporate finance literature. Following Roll (1986) pioneering study on the role of managerial over optimism in corporate acquisitions, the merits of managers' possible departure from full rationality, and behavioral corporate finance in general, have been examined in a number of theoretical and empirical studies.

Heaton (2002) focuses on optimism in a corporate setting. In particular, he discusses lucidly why the arbitrage and the learning objection are weaker in corporate settings. Biased managers in his two-date model perceive risky corporate securities to be undervalued by the market, may reject positive net present value project if (seemingly costly) external funds are needed to finance them, and may invest in negative net present value projects because of biased cash flow forecasts. Indeed, this optimistic leader tend to overestimate the value of their project, they are reluctant to increase their capital by considering that the market systematically evaluates the value of securities. Baker et al. (2007) show that optimistic CEOs over invest and tend to choose higher leverage. Optimist CEO overestimates this firm growth opportunities and seeks to achieve even with the use of external financing methods. Ben-David and al (2006) calculate optimism and overconfidence measures. They find that firms with optimistic leaders invest more. Strengthening a leader involvement sense encourages optimism on the investment.

Wang (2006) finds that misreporting firms are more likely to over-invest in specific investment and stock-financed mergers and acquisitions. Hackbarth (2009) argue that optimistic managers have a higher probability to excel in tournaments and thus may get promoted to top executive positions more often, though all managers choose riskier investments (specific investment and long term) when faced by internal competition for leadership. This optimistic leader opts for specific investments such as investment in research and development in order to increase the competitiveness of its business and ensure the firm value creation. Gervais and Odean (2001), Bais et al. (2005), Chuang et al. (2009), show the existence of a positive relationship between overconfidence (and / or optimism) and uncertainty. This uncertainty regarding the adequacy of available information affects decision making. This reflects the negative relationship between managerial optimism and riskier investment level.

\section{H1: Optimistic leader over-invested in specific investment projects.}

\subsection{Loss aversion and investment decision}

A nascent literature recognizes that the bias of loss aversion is a significant determinant of manager financing decisions. Psychological studies document that loss aversion causes people to overestimate risk, be more uncertain about forecasts and opt for making it safer to limit the likelihood of his removal. Baker et al. (2007) in their excellent review of the growing literature on behavioral corporate finance, several managerial behavioral biases have shown to affect corporate decisions. Bertrand and Mullainathan (2003), argue that leaders can be encouraged not to invest so as not to be challenged in their "quiet life". This kind of conservatism is a way to counteract the risk of loss of control (Barberis \& Thaler, 2002). Thus, the loss aversion of the manager due to a hostile takeover bid (hostile takeover) forces him not to invest in projects with positive returns if financed by issuing shares.

Mairesse and Mohnem (2005) show that investment in research and development plays a key strategic role for any innovative company. Due to the high costs and risks inherent in specific investment, the leader is forced to consider the capacity to effectively implement. This reflects the negative relationship between managerial loss aversion level and firms' investment specific level. One explanation is that the individual, by nature, seeks to maximize and improve well-being constantly (Helliar et al., 2005; Albouy and Schatt, 2010 ; Nosic and Weber, 2008). It is particularly annoying 
to see its financial assets to deteriorate in each period. Individuals working in the financial world have already met most of their needs and tend to self-esteem that wishes to satisfy (Maslow, 1989). So any leader could be threatened by the loss of social status seeks to enhance its work at the head of his company through low firm investment specific level to reduce firm risk (or his loss aversion).

\section{H2: Loss aversion leader under-invested in specific investment projects.}

\subsection{Overconfidence and investment decision}

Recent studies have documented the presence of managerial over-confidence and the effects it has on corporate policies. Baker et al. (2004) survey the extant research and point out that over-confidence affects many aspects of corporate financing including both investment and financing policies. BenDavid et al. (2007); Sautner and Weber (2009) use survey evidence to show that the over-confidence of top executives affects various corporate decisions, including the investment policy of the firm. An overconfident CEO persistently feels undervalued by the capital market and is thus reluctant to issue risky securities to finance his projects (Heaton, 2002). The perceived undervaluation induces CEOs to abstain from projects and underinvested when they cannot be financed without tapping the resources of (unbiased) outsiders (Malmendier and Tate, 2005-2008). Gervais et al. (2010) stress that the executive overconfidence overestimate its powers to reduce the risk of his business. It tends therefore to invest more than a rational manager. Ho and Chang (2009) postulate the presence of a positive relationship between the company financial distress and CEO overconfidence level. Thus, overconfidence leads the manager to underestimate the company bankruptcy probability and, therefore, a higher debt. It seeks to exploit the growth opportunuités of its firm. This reflects the positive relationship between managerial over confidence and firm over- investment level.

Goel and Thakor (2000) argue that overconfident managers have a higher probability to excel in tournaments and thus may get promoted to top executive positions more often, though all managers choose riskier investments when faced by internal competition for leadership. Schrand and Zechman (2010) emphasize that overconfidence is positively associated with the overestimation of the probability of success and the presence of biased financial decisions. The leader overconfidence that overestimates his personal skills tends to choose financial decisions inconsistent with the firm characteristics. It underestimates the risk of bankruptcy of his company and believes the control. These beliefs led him to increase the specific investment level of the business. Simon and Houghton (2003) suggest that overconfident managers are more likely to pursue risky behavior. This reflects the negative relationship between managerial overconfidence and riskier investment level (specific investment). Graham et al. (2009) suggest that overconfident managers are better innovators.

H1: overconfidence leader over-invested in specific investment projects.

\section{Research method}

\subsection{Data}

Our empirical study is based on quantitative research. we use a questionnaire as a method of data collection. Our questionnaire consists of four main parts, based ontreated areas in theory:

* The first part aims to identify the company (size, industry, ownership structure, debt levels, level of dividend distribution, ....).

* The second part focuses on presenting the level of loss aversion leaders.

* Party three deals with the level of optimism of the leader.

* Finally, party four seeks to show the level of overconfidence of managers. 
The questionnaire is addressed to CEO of Tunisian companies. The selected sample consists of 100 managers of industrial and commercial companies listed on the tunisian stock exchange in 2010 (28 companies) and rnon-listed companies ( 82 companies). Our choice of listed companies is justified by the fact that they are supposed to the most efficient and meet several conditions necessary for the reliability of our study were limited companies which are usually diffuse shareholders, increasing the importance of role of the board and ownership structure and consequently increase the validity of the assumptions. We decided to exclude financial firms: banks, insurance companies and investment companies for development and portfolio management... in fact these companies have different characteristics of non-financial businesses and to avoid correlation effects specific to a specific sector. To get a representative sample of our Tunisian market we have added other unlisted companies.

\section{Table 1}

Visited Companies

Initial BVMT sample for 2007

financial firms

Other non financial firms

Insufficient data to emotional intelligence

Insufficient data to board of directors compositions

Final sample

\subsection{Variables' measurement}

The objective of this section is to determine the variables' measurement.

\subsubsection{Firms' investment decision}

The purpose of this article is to show the impact of emotions on the firms' investment decision (investment nature, level and horizon). The appropriate measures in the literature to evaluate investment decision are:

\subsubsection{Assets specificity}

In our study, we will use the degree of assets intangibility as a proxy of the specific investments. The degree of assets intangibility can be appreciated on many levels. The France Bank and Ministry of Industry in studies devoted to the development of intangible investments in France have used the ratio often intangible / tangible assets. In Tunisia, as in France, the intangible asset accounting record comes from the capitalization of such expenses. However, the unavailability of information legitimizes the use of the amount of intangible assets is presented in the balance sheet although this amount is usually surrounded by doubt as the result of discretionary choices performed by the leaders. Akin to the French context, the measurement of intangible capital in the Tunisian context has the same problems, which leads us to adopt accounting.

Based on that discussion and the availability of data of Tunisian companies we offer the following indicator of the degree of activation of intangible expenses:

\section{Asset Specificity Rate (ASR) = intangible assets / asset accounting.}

This measured is used by Cazavan-Jeny (2004), Moussu and Thibierge (1997), Thibierge (2001), etc.

\subsubsection{Investment level}

In this study, we will use the presence of free cash flow and growth opportunities as two indicators of over-investment (low Future investment opportunities and free cash flow) or 
underinvestment (low free cash flow and Future investment opportunities). The literature differs on how to measure the free cash flow as conceptualized by Jensen (1986). In general, however, it is defined as operating income before depreciation interest expense and taxes, as well as dividends paid (Lehn \& Poulsen, 1989; Gul \& Tsui, 1998; Jaggi \& Gul, 1999) divided by book value of total assets to account for effects related to size (Lang et al., 1991).

\section{Free Cash Flow Rate (FCFR) = Operating profit / total assets.}

Future investment opportunities are measured by Tobin's Q (Skinner, 1993). Tobin's Q is defined as the ratio of market value of a firm to the replacement value of its assets (Lindenberg and Ross, 1981; Griliches, 1981; Cockburn and Griliches, 1988; Megna and Klock, 1993; Skinner, 1993). A Tobin's Q greater than one then the company has signed a profitable investment opportunities and vice versa. In our study, we will retain an approximation of Tobin's Q, calculated as follows (Chung \& Pruitt, 1994):

$$
Q_{i t} \cong \frac{M V S_{i t}+D_{i t}}{A_{i t}}
$$

MVS - market value of common and preferred shares; D - book value of debt, defined as current liabilities plus long-term debt plus inventories minus current assets; A - total assets.

\subsubsection{Investment horizon}

Referring to the theory of agency leaders has an obligation of result on short horizons. Their wealth is tied to the performance of the firm during the duration of their mission is the period during which they run the firm. These leaders prefer investment projects in the short term to quickly reveal the performance of these investments and reduce uncertainty about their own value on the labor market (Narayanan, 1985).

In our study we will use the rate of investment operations (industrial and commercial assets) as an indicator of the investment horizon.

\section{Capital Expenditure Rate $($ CER) = operating assets / Total assets}

This measured is used by Cliche (2000), Gervais et al. (2002), Malmendier and Tate (2005), Chang et al. (2009), Drairef (2010), etc.

The investment decision takes 9 follows:

- 1 if the manager chooses investment specific: positive variation in the rate of assets specificity.

- 2 if the manager chooses overinvestment: low future investment opportunities and free cash flow

- 3 if the manager chooses underinvestment: low free cash flow and future investment opportunities.

- 4 if the manager chooses long-term investment: negative variation in the rate of capital expenditure

- 5 if the manager chooses short-term investments: positive variation in the rate of capital expenditure.

- 6 if the manager chooses (overinvestment+ long-term investment): negative variation in the rate of capital expenditure, low future investment opportunities and free cash flow.

- 7 if the manager chooses (underinvestment+ short-term investments): positive variation in the rate of capital expenditure, low free cash flow and future investment opportunities. 
- 8 if the manager chooses (specific investment + overinvestment + long-term investment): positive variation in the rate of assets specificity, negative variation in the rate of capital expenditure, low future investment opportunities and free cash flow.

- 9 if the manager chooses specific investment+ underinvestment + long-term investment): positive variation in the rate of assets specificity, low free cash flow, future investment opportunities and negative variation in the rate of capital expenditure.

\subsubsection{Emotional bias}

The questionnaire focuses on evaluating and scoring of the three emotional biases (risk aversion, optimism and overconfidence). The questions have been inspired from the questionnaires formulated by the Fern Hill and Industrial Alliance companies.

The emotional bias takes 2 follows:

- 1 if the individual has a high level for each bias

- 0 if not

\subsubsection{Capital structure choice}

The appropriate measures in the literature to evaluate three methods of financing are:

\subsubsection{Internally generated resources (The Cash Flow)}

Research within the framework of financial theory of investment, have resorted tomany measures of internal resources. Cash flow represents the flow generated by the activity of any business, is one of the most appropriate (Lehen and Poulsen, 1989; Molay, 2006; Naoui and al, 2008; ...).

\section{CF $=$ Net income + Depreciation - Dividend}

Casch Flow rate $(\mathrm{RCF})=\mathrm{CF} /$ Total Assets

To show that the leader chosen or not internaly generated ressources, we can use the change in flow rate. A negative change indicates the use of internal resources.

\section{Cash flow rate variation $=\mathbf{R C F}_{\mathrm{N}^{-}} \mathbf{R C F}_{\mathrm{N}-1} / \mathbf{R C F}_{\mathrm{N}-1}$}

\subsubsection{Debt level}

We observe a variety of variables that measure the level of debt in the company.Measures such as total debt service ratio has been selected by several authors (Hovakimian and al, 2004). Others have used the debt ratio in the medium and long term (Myers, 2001). The debt ratio in the short term was also used by Titman (1984).

As part of our analysis we propose to use the debt ratio as a measure of this variable. It should be noted that this ratio is calculated by:

\section{Leverage ratios $(\mathrm{LEV})=($ total debt $/$ total assets $)$}

This measure is also used by Koh (2003),Demaria and Dufour (2007), Jarboui and Olivero (2008), Ben Kraiem (2008) and Sahut and Gharbi (2008). To show that the manager uses debt or not, we can use the change in debt ratio. A positive change indicates the use of debt.

Leverage ratios variation $=\mathbf{L E V}_{\mathrm{N}^{-}} \mathbf{L E V}_{\mathrm{N}-1} / \mathrm{LEV}_{\mathrm{N}-1}$ 


\subsubsection{Equity level}

This variable is measured by the value of equity in the balance sheet of the company.To show that the leader chosen or not the capital increase, we can use the variationin the percentage of investment. A positive change indicates an increase of capital.

Level of Capital Invested (LCI) = equity / total assets

\section{Level of Capital Invested Variation $=\mathbf{L C I}_{\mathrm{N}^{-}} \mathbf{L C I}_{\mathrm{N}-1} / \mathbf{L C I}_{\mathrm{N}-1}$}

The financial decision takes 7 follows:

- 1 if the manager chooses the internally generated resources: positive variation in the cash flow rate.

- 2 if the manager chooses debt: positive variation in the leverage ratio.

- 3 if the manager chooses the capital increase: positive variation in the level of invested capital.

- 4 if the manager chooses internally generated resources + debt : positive variation in the cash flow rate and debt ratios.

- 5 if the manager chooses internally generated resources + capital increase: positive variation in the cash flow rate and level of capita invested.

- 6 if the manager chooses debt + capital increase: positive variation in the leverage ratio and level of invested capital.

- 7 if the manager chooses internally generated resources + debt + capital increase: positive variation in the cash flow rate, leverage ratio and level of invested capital.

\subsubsection{Control variables}

Static trade-off theory ( STT) and pecking order theory (POT) is the body of theory of reference that addressed the issue of the financial structure of the firm. The factors that explain the financial structure are mainly at the cost, size, level of risk, growth opportunities, the structure of assets and business (Rajin and Zingales, 1995;Booth and al, 2001; Molay and Dufour, 2010).

We include in our model three control variables that explain the effectiveness ofchoice of financial structure of the company. These variables are proxies for profitability, firm size and growth opportunities.

\subsubsection{Profitability}

More profitable firms have, ceteris paribus, more internally generated resources to fund new investments. If their managers follow a pecking order, they will be less likely to seek external financing (Fama \& French, 2002). Thus, on average, these firms' leverage ratios will be lower. In trade-off models, on the other hand, this relationship is inverted. More profitable firms are less subject to bankruptcy risks, ceteris paribus. Hence, their expected bankruptcy costs are reduced and they can make more use of the tax shields provided by debt, thus choosing a position of greater leverage. We will keep the ratio of return on assets ROA to measure this variable:

\section{ROA= Earnings before interest, tax, depreciation divided by total assets, lagged one year period}




\subsubsection{Firm size}

Studies suggest that the probability of bankruptcy is lower in larger firms and that, therefore, their debt capacity is higher than that of smaller ones, all else equal. On the other hand, fixed transaction costs can make new stock issues unattractive to small corporations, stimulating them to issue debt (Rajin \& Zingales, 1995; Hovakimian et al., 2004; Dufour \& Molay, 2010).

Indeed, most studies have applied total assets or turnover as a measure for firm size (Bujadi \& Richardson, 1997). In this paper, it is measured through the log of the firm's total assets (LNSIZE).

\subsubsection{Future investment opportunities}

It is argued that future profitable investment opportunities can influence corporate financing decisions in different ways. In the context of the pecking order theory, firms that have many investment opportunities and believe that their stocks (and risky bonds) are undervalued by the market, may choose a capital structure with less debt. If they maintained high debt ratios, they would be forced to distribute precious cash flows generated by their business and could face the need to issue undervalued securities to fund new projects. This could, in turn, induce underinvestment. A more static version of the pecking order model, on the other hand, predicts that firms with more future opportunities will be more levered, ceteris paribus, because they need more external financing and issuing debt is preferable to issuing new stock Rajin \& Zingales, 1995; Graham, 2000 ; Booth et al., 2001; Dufour \& Molay, 2010 ; Naoui et al., 2008).

We will keep the Tobin's Q to measure this variable. The Tobin's Q Estimated with the approximation formula proposed by Chung and Pruitt (1994):

$$
Q_{i t} \cong \frac{M V S_{i t}+D_{i t}}{A_{i t}}
$$

MVS - market value of common and preferred shares; D - book value of debt, defined as current liabilities plus long-term debt plus inventories minus current assets; A - total assets.

For simplification purposes, the summary of each variable extent range in the model, its name as well as its expected impact on the capital structure choice are depicted in Table 2.

\subsection{Bayesian Network Method}

The definition of a Bayesian network can be found in many versions, but the basic form (Pearl, 1986) is stated as follows: a Bayesian network is a directed probability graph, connecting the relative variables with arcs, and this kind of connection expresses the conditional dependence between the variables. The formal definition follows.

A Bayesian network is defined as the set of $\{\mathrm{D}, \mathrm{S}, \mathrm{P}\}$, where.

(1) D is a set of variables (or nodes): in our case it consists of capital structure choice, optimism, loss aversion, overconfidence, profitability, firm size and future investment opportunities.

(2) $\mathrm{S}$ is a set of conditional probability distributions (CPD). $S=\{p(D / P a r e n t s(D) / D \in D\}$, Parents(D) $\subset \mathrm{D}$ stands : for all the parent nodes for $\mathrm{D}, \mathrm{p}(\mathrm{D} / \operatorname{Parents}(\mathrm{D})$ is the conditional distribution of variable $\mathrm{D}$.

(3) $\mathrm{P}$ is a set of marginal probability distributions. $\mathrm{P}=\{\mathrm{p}(\mathrm{D}) / \mathrm{D} \in \mathrm{D}\}$ stands for the probability distribution of variable $\mathrm{D}$. 
Table 2

Operational definitions of variables

\begin{tabular}{|c|c|c|c|c|c|c|}
\hline Class: & Phenomena: & Mesure : & Variables: & \multicolumn{3}{|c|}{ Predictions : } \\
\hline \multicolumn{7}{|c|}{ Endogens variables : } \\
\hline \multirow[t]{4}{*}{$\begin{array}{l}\text { Investment } \\
\text { decision }\end{array}$} & Assets specificity & $\begin{array}{l}\text { Asset Specificity Rate (ASR) = intangible } \\
\text { assets / asset accounting. }\end{array}$ & $\mathrm{AS}$ & & & \\
\hline & Investment level & $\begin{array}{l}\text { Free Cash Flow Rate }(\text { FCFR })=\text { Operating } \\
\text { profit / total assets. } \\
\text { and }\end{array}$ & INL & & & \\
\hline & & $Q_{i t} \cong \frac{M V S_{i t}+D_{i t}}{A_{i t}}$ & & & & \\
\hline & Investment horizon & $\begin{array}{l}\text { Capital } \quad \text { Expenditure } \quad \text { Rate } \\
(\mathrm{CER})=\text { operating assets } / \text { Total assets }\end{array}$ & INH & & & \\
\hline \multicolumn{7}{|c|}{ Exogenous variables: } \\
\hline & & & & $\mathrm{CF}$ & $\mathrm{LEV}$ & $\mathrm{EQ}$ \\
\hline Optimism & $\begin{array}{l}\text { Directors } \\
\text { overestimate capacity } \\
\text { of their firms }\end{array}$ & The questionnaire obtained score & $\mathrm{OP}$ & + & + & - \\
\hline Lost aversion & $\begin{array}{l}\text { Loss rumination and } \\
\text { reputation }\end{array}$ & The questionnaire obtained score & LA & + & - & + \\
\hline overconfidence & $\begin{array}{l}\text { Directors } \\
\text { overestimate their } \\
\text { personal } \\
\text { competences }\end{array}$ & The questionnaire obtained score & OVER & + & + & + \\
\hline \multirow[t]{3}{*}{$\begin{array}{l}\text { Capital } \\
\text { structure } \\
\text { choice }\end{array}$} & $\begin{array}{l}\text { Internally generated } \\
\text { resources (The Cash } \\
\text { Flow) }\end{array}$ & $\begin{array}{l}\mathrm{CF}=\text { Net income }+ \text { Depreciation }- \\
\text { Dividend } \\
\text { Casch Flow rate }(\mathrm{RCF})=\mathrm{CF} / \text { Total Assets } \\
\text { ) } \\
\text { Cash flow rate variation }=\mathrm{RCF}_{\mathrm{N}^{-}} \mathrm{RCF}_{\mathrm{N}-1} \\
/ \mathrm{RCF}_{\mathrm{N}-1}\end{array}$ & $\mathrm{CF}$ & + & + & - \\
\hline & Debt level & $\begin{array}{l}\text { Leverage ratios }(\mathrm{LEV})=(\text { total debt } / \\
\text { total assets }) \\
\text { Leverage ratios variation }=\mathrm{LEV}_{\mathrm{N}^{-}} \mathrm{LEV}_{\mathrm{N}-1} \\
/ \mathrm{LEV}_{\mathrm{N}-1}\end{array}$ & LEV & - & + & + \\
\hline & Equity level & $\begin{array}{l}\text { Level of Capital Invested (LCI) = equity / } \\
\text { total assets } \\
\text { Level of Capital Invested Variation = } \\
\mathrm{LCI}_{\mathrm{N}}-\mathrm{LCI}_{\mathrm{N}-1} / \mathrm{LCI}_{\mathrm{N}-1}\end{array}$ & EQ & + & - & + \\
\hline \multicolumn{7}{|c|}{ Controls variables: } \\
\hline Profitability & $\begin{array}{l}\text { Reports on } \\
\text { the company's } \\
\text { ability to meet its } \\
\text { commitments }\end{array}$ & $\begin{array}{l}\mathrm{ROA}=\text { Earnings before interest, tax, } \\
\text { depreciation divided by total assets, } \\
\text { lagged one year period }\end{array}$ & $\overline{\mathrm{PF}}$ & + & + & - \\
\hline Firm size & $\begin{array}{l}\text { Firms signaled } \\
\text { performance }\end{array}$ & Ln (total assets) & LNSIZE & + & + & + \\
\hline $\begin{array}{l}\text { Future } \\
\text { investment } \\
\text { opportunities }\end{array}$ & $\begin{array}{l}\text { Indicates the } \\
\text { productive } \\
\text { capacity of the } \\
\text { company }\end{array}$ & $\begin{array}{l}Q_{i t} \cong \frac{M V S_{i t}+D_{i t}}{A_{i t}} \\
\text { MVS - market value of common and } \\
\text { preferred shares; D - book value of debt, } \\
\text { defined as current liabilities plus long-term } \\
\text { debt plus inventories minus current assets; } \\
\text { A - total assets. }\end{array}$ & FIO & - & + & + \\
\hline
\end{tabular}

In the Bayesian network, variables are used to express the events or objects. The problem could be modeled with the behavior of these variables. In general, we first calculate (or determine from expert 
experience) the probability distribution of each variable and the conditional probability distribution between them. Then from these distributions we can obtain the joint distributions of these variables. Finally, some deductions can be developed for some variables of interest using some other known variables.

In our study, we try to show the evolution of CEO financing choices according to the evolution of his emotions and his company characteristics. Thus, theoretically, have to show that the company capital structure choice (Internally generated resources, debt and Equity) depends on: CEO emotional biases (CEO optimism level, loss aversion and overconfidence), firm profitability, firm size and firm future investment opportunities.

\subsubsection{Define network variables and values}

The first step in building a Bayesian network expert is to list the variables recursively, starting from the target variable to the causes. In this order we present the variables in the table below:

\section{Table 3}

The network variables and their values

\begin{tabular}{ll}
\hline Variables & Type \\
\hline Investment decision & Discret $[1 ; 2 ; 3 ; 4 ; 5 ; 6 ; 7 ; 8 ; 9]$ \\
Capital structure choice & Discret $[1 ; 2 ; 3 ; 4 ; 5 ; 6 ; 7]$ \\
Optimism & Discret : YES/NO \\
Loss aversion & Discret : YES/NO \\
overconfidence & Discret : YES/NO \\
Profitability & Discret : YES/NO \\
Firm size & Discret $[1 ; 2 ; 3]$ \\
Future investment opportunities & Discret : YES/NO \\
\hline
\end{tabular}

\subsubsection{Graphical model}

The second step of Bayesian network the construction is to express the relationships between variables. The BayesiaLab learning of Bayesian network by taking the database as a discrete entry process without sampling data. The Bayesian network constructed is the result for the total database. According to the data that we have received through the questionnaire, we have established relationships following graph (Fig. 1).

\section{Empirical results}

\subsection{The relationships discovered analysis}

The relationships between the variables in the database are directed at the parent node child node.

Each relationship is composed of three different measures: the Kullback-Leibler, the relative weight and the Pearson correlation (direction of relation). Indeed, the Kullback-Leibler and the relative weight are two measures indicating the strength of relationships and the level correlation between variables, in that while the correlation measure of personal meaning and relationship significance.

The relative weight scale of 0 to 1 . Thus, the table (Table 3 ) below shows the relationships analysis results between variables across the network Pearson correlation. 


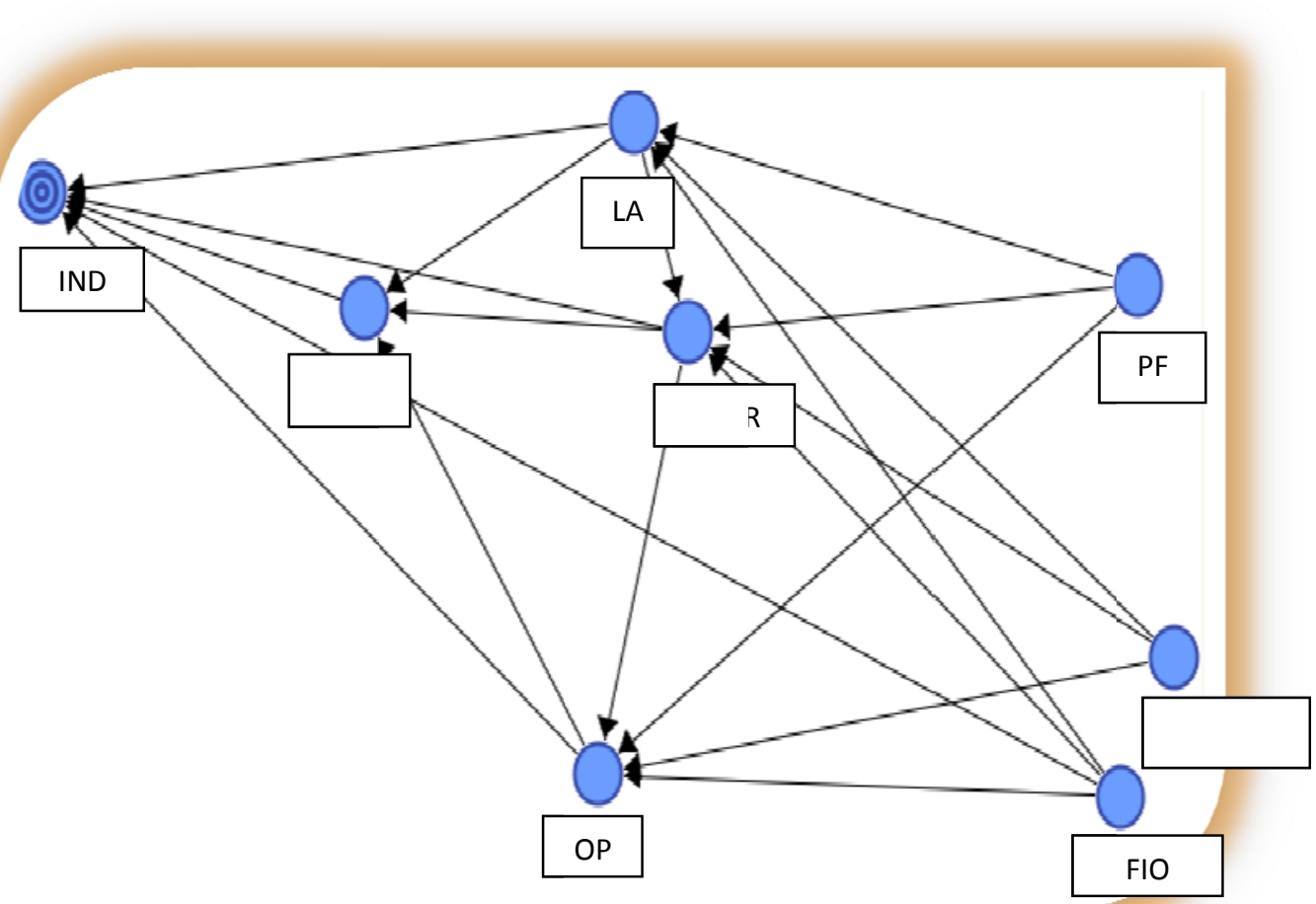

Fig. 1. Investment decision: Bayesian network

Table 4

The relationships analysis

\begin{tabular}{lllll}
\hline Parents nodes & Childs nodes & Kullback-Leibler divergence & Poids relatif & Relative weight \\
\hline CSC & IND & 0,976628 & 1,0000 & $0,1848^{*}$ \\
FIO & IND & 0,720238 & 0,7375 & 0,2702 \\
OP & CSC & 0,631802 & 0,6469 & $-0,0985^{*}$ \\
OVER & IND & 0,470045 & 0,4813 & $0,1531^{*}$ \\
LA & IND & 0,371970 & 0,3809 & $-0,0912^{*}$ \\
LA & CSC & 0,322634 & 0,3304 & $-0,1251^{*}$ \\
OP & IND & 0,226392 & 0,2318 & $-0,1186^{*}$ \\
OVER & CSC & 0,225408 & 0,2308 & 0,3086 \\
FSIZE & LA & 0,193522 & 0,1982 & $-0,3519$ \\
FSIZE & OP & 0,191295 & 0,1959 & 0,2133 \\
FIO & OVER & 0,135048 & 0,1383 & $0,0346^{* *}$ \\
PF & OVER & 0,134062 & 0,1373 & $0,1251^{*}$ \\
FSIZE & OVER & 0,108402 & 0,1110 & $0,0429^{* *}$ \\
FIO & OP & 0,097059 & 0,0994 & $-0,0688^{*}$ \\
PF & OP & 0,096918 & 0,0992 & $0,1714^{*}$ \\
PF & LA & 0,077256 & 0,0791 & $-0,1662^{*}$ \\
LA & OVER & 0,053792 & 0,0551 & $-0,1555^{*}$ \\
FIO & LA & 0,044916 & 0,0460 & $-0,0308^{* *}$ \\
OVER & OP & 0,042004 & 0,0430 & $-0,0159^{* * *}$ \\
\hline
\end{tabular}

a.Kullback-Leibler close to 1: important correlation between the variables

b.Relative weight close to 1 : important correlation between the variables.

c.Pearson correlation:***,***, respectively at $10 \%, 5 \%, 1 \%$.

Table 4 examines the relationship (strength and correlation type) between networks variables.

The analysis of the relations shows the presence of a strong relationship (Kullback-Leibler $=0976$ / weight rate $=1)$ and positive $(\beta=0.1848)$ between investment decision and financing decision. This 
confirms the predictions of financial theory for organizational independence between the two decisions. The optimism of the leader affects (Kullback-Leibler $=0.7202 / 0.2318=$ weight rate) negatively $(\beta=-0.1186)$ the investment decision of his business. This result confirms our hypothesis (H1, H2 and $\mathrm{H} 3$ ) and shows that the optimism of the leader is correlated positively with the presence of an investment decision sub-optimal (high specificity, over-investment and longhorizon).

Loss aversion is correlated (Kullback-Leibler $=0.3719 / 0.3809=$ weight rate) negatively $(\beta=$ 0.0912) with his investment choices. This finding validates our theoretical predictions (H5, H6). It shows that emotions or emotional biases affect the rationality of managerial decisions which the investment decision.

Overconfidence leader's influence (Kullback-Leibler $=0.47 /$ weight rate $=0.4813$ ) positively $(\beta=0.1531)$ the investment decision of his business. This result confirms our theoretical development (H7, H8 and H9) and shows that emotional biases affect managerial decisions including investment decisions. The results show a strong relationship (KullbackLeibler $=0.2263 / 0.7375=$ weight rate $)$ and not significant $(\beta=0.2702)$ between growth opportunities and investment decisions. Network investment decision analysis confirms financing decision results. Thus, the financing decision is negatively correlated with the optimism level $(\beta=-$ $0.0985)$ and loss aversion $(\beta=-0.1251)$.

Analysis shows that firm size affects their emotional state. Thus, the size negatively affects CEO loss version level $(\beta=-0.3519)$, positively correlated with leader optimism rate $(\beta=0.2133)$ and CEO overconfidence level $(\beta=0.0429)$. Growth opportunities are positively correlated with the level of overconfidence $(\beta=0.0346)$ and negatively with the leader's loss aversion level $(\beta=-0.0688)$ and optimism $(\beta=-0.0308)$. Firm profitability is negatively correlated with CEO loss aversion level $(\beta=-$ $0.1662)$, positively correlated with his optimism level $(\beta=0.1714)$ and overconfidence level $(\beta=0.1251)$. Relationships analysis shows a negative correlation between CEO loss aversion rate of and his overconfidence level $(\beta=-0.1555)$. Finally, the results also show a negative correlation between managerial overconfidence and optimism level $(\beta=-0.0159)$.

\subsection{Target variable analysis: investment decision (IND)}

To analyze the capital structure choice, we must choose the variable investment decision as a target variable in the Bayesian network. Then we can use the function that generates the analysis report of the target investment decision. In this report, the relationship between investment decision and the other variables are measured by binary mutual information and the binary relative importance. The mutual information of two random variables is a score measuring the statistical dependence of these variables. It is measured in bits.

Investment decision analysis shows that $14.21 \%$ of Tunisian companies opt for the combination ( specific investment + long term + under-investment), $12.2 \%$ use their financial capabilities to overinvest, $12.11 \%$ prefer specific investments, $11.24 \%$ overinvested in long-term projects, $11.4 \%$ choose the short-term investments, $11.08 \%$ overinvest in specific projects and longterm, 9.4\% prefer short-term investments and limit the presence of a long-term investment by the under-investment, $7.48 \%$ choosing long-term investment.

The results show that $87.74 \%$ of growth opportunities, $32.95 \%$ of preferred equity, $50.97 \%$ of CEO risk appetite, $53.37 \%$ of CEO optimism and a firm great size to $58.72 \%$ involve the use of specific investments in the long term and the presence of under-investment situations with a probability of $14.21 \%$. 
Table 5

Traget variable analysis

\begin{tabular}{|c|c|c|c|c|}
\hline \multicolumn{5}{|c|}{$\mathrm{IND}=\mathrm{AS}+\mathrm{LTIN}+\mathrm{UNINV}(14,21 \%)$} \\
\hline Nodes & Binary mutual information & Binary relative importance & Modal value & \\
\hline $\mathrm{OC}$ & 0,0555 & 1,0000 & YES & $87,74 \%$ \\
\hline $\mathrm{CSC}$ & 0,0259 & 0,4663 & EQ & $32,95 \%$ \\
\hline LA & 0,0085 & 0,1525 & NO & $50,97 \%$ \\
\hline OP & 0,0016 & 0,0290 & YES & $53,37 \%$ \\
\hline FSIZE & 0,0007 & 0,0127 & BIG & $58,72 \%$ \\
\hline $\mathrm{PF}$ & 0,0001 & 0,0023 & NO & $54,36 \%$ \\
\hline OVER & 0,0001 & 0,0022 & YES & $60,91 \%$ \\
\hline \multicolumn{5}{|c|}{ IND = OVERINV $(12,20 \%)$} \\
\hline Nodes & Binary mutual information & Binary relative importance & Modal value & \\
\hline FIO & 0,0937 & 1,0000 & YES & $90,01 \%$ \\
\hline $\mathrm{CSC}$ & 0,0730 & 0,7788 & $\mathrm{CF}$ & $36,84 \%$ \\
\hline OP & 0,0324 & 0,3457 & YES & $85,43 \%$ \\
\hline OVER & 0,0196 & 0,2090 & NO & $62,58 \%$ \\
\hline $\mathrm{PF}$ & 0,0037 & 0,0396 & YES & $53,58 \%$ \\
\hline FSIZE & 0,0025 & 0,0272 & BIG & $62,22 \%$ \\
\hline LA & 0,0008 & 0,0082 & YES & $57,85 \%$ \\
\hline \multicolumn{5}{|c|}{ IND $=$ AS $(12,11 \%)$} \\
\hline Nodes & Binary mutual information & Binary relative importance & Modal value & \\
\hline $\mathrm{CSC}$ & 0,0151 & 1,0000 & EQ & $28,71 \%$ \\
\hline FIO & 0,0082 & 0,5449 & $\mathrm{NO}$ & $58,33 \%$ \\
\hline LA & 0,0044 & 0,2891 & YES & $72,08 \%$ \\
\hline FSIZE & 0,0029 & 0,1948 & BIG & $51,54 \%$ \\
\hline OVER & 0,0013 & 0,0894 & YES & $53,59 \%$ \\
\hline PF & 0,0001 & 0,0091 & NO & $54,15 \%$ \\
\hline OP & 0,0000 & 0,0004 & YES & $58,73 \%$ \\
\hline \multicolumn{5}{|c|}{ IND = LT+OVERINV $(11,24 \%)$} \\
\hline Nodes & Binary mutual information & Binary relative importance & Modal value & \\
\hline OVER & 0,0381 & 1,0000 & YES & $88,73 \%$ \\
\hline $\mathrm{CSC}$ & 0,0232 & 0,6099 & $\mathrm{CF}+\mathrm{LEV}$ & $26,33 \%$ \\
\hline LA & 0,0214 & 0,5610 & $\mathrm{NO}$ & $61,75 \%$ \\
\hline FIO & 0,0186 & 0,4876 & NO & $66,39 \%$ \\
\hline OP & 0,0121 & 0,3175 & NO & $58,95 \%$ \\
\hline FSIZE & 0,0082 & 0,2141 & BIG & $72,50 \%$ \\
\hline $\mathrm{PF}$ & 0,0004 & 0,0103 & NO & $52,74 \%$ \\
\hline \multicolumn{5}{|c|}{ IND $=$ ST $(11,14 \%)$} \\
\hline Nodes & Binary mutual information & Binary relative importance & Modal value & \\
\hline $\mathrm{CSC}$ & 0,0445 & 1,0000 & EQ & $36,16 \%$ \\
\hline OP & 0,0194 & 0,4361 & $\mathrm{NO}$ & $63,86 \%$ \\
\hline $\mathrm{PF}$ & 0,0050 & 0,1128 & NO & $67,54 \%$ \\
\hline LA & 0,0021 & 0,0478 & YES & $69,45 \%$ \\
\hline OVER & 0,0016 & 0,0357 & YES & $52,79 \%$ \\
\hline FSIZE & 0,0015 & 0,0343 & BIG & $55,05 \%$ \\
\hline FIO & 0,0002 & 0,0035 & YES & $53,93 \%$ \\
\hline \multicolumn{5}{|c|}{ IND = UNDINV $(11,14 \%)$} \\
\hline Nodes & Binary mutual information & Binary relative importance & Modal value & \\
\hline OVER & 0,0511 & 1,0000 & YES & $90,46 \%$ \\
\hline $\mathrm{CSC}$ & 0,0222 & 0,4342 & $\mathrm{CF}$ & $27,93 \%$ \\
\hline LA & 0,0074 & 0,1449 & YES & $75,61 \%$ \\
\hline OP & 0,0058 & 0,1138 & YES & $71,34 \%$ \\
\hline FSIZE & 0,0011 & 0,0216 & BIG & $64,73 \%$ \\
\hline $\mathrm{PF}$ & 0,0010 & 0,0200 & NO & $61,25 \%$ \\
\hline OVER & 0,0007 & 0,0139 & YES & $54,96 \%$ \\
\hline $\mathrm{IND}=\mathrm{A}$ & & & & \\
\hline Nodes & Binary mutual information & Binary relative importance & Modal value & \\
\hline $\mathrm{CSC}$ & 0,0263 & 1,0000 & $\mathrm{LEV}+\mathrm{EQ}$ & $24,96 \%$ \\
\hline LA & 0,0063 & 0,2391 & YES & $74,62 \%$ \\
\hline FIO & 0,0015 & 0,0557 & NO & $50,35 \%$ \\
\hline OVER & 0,0014 & 0,0528 & YES & $65,39 \%$ \\
\hline FSIZE & 0,0011 & 0,0405 & BIG & $57,15 \%$ \\
\hline $\mathrm{PF}$ & 0,0009 & 0,0347 & NO & $60,98 \%$ \\
\hline OP & 0,0000 & 0,0005 & YES & $59,71 \%$ \\
\hline $\mathrm{IND}=\mathrm{S}$ & & & & \\
\hline Nodes & Binary mutual information & Binary relative importance & Modal value & \\
\hline FIO & 0,0375 & 1,0000 & YES & $88,69 \%$ \\
\hline $\mathrm{CSC}$ & 0,0149 & 0,3973 & EQ & $29,15 \%$ \\
\hline OVER & 0,0030 & 0,0803 & YES & $69,05 \%$ \\
\hline OP & 0,0021 & 0,0564 & YES & $67,28 \%$ \\
\hline PF & 0,0007 & 0,0190 & NO & $51,15 \%$ \\
\hline LA & 0,0001 & 0,0020 & YES & $63,63 \%$ \\
\hline FSIZE & 0,0000 & 0,0006 & BIG & $59,47 \%$ \\
\hline $\mathrm{IND}=\mathrm{L}$ & & & & \\
\hline Nodes & Binary mutual information & Binary relative importance & Modal value & \\
\hline $\mathrm{CSC}$ & 0,0144 & 1,0000 & EQ & $33,81 \%$ \\
\hline FIO & 0,0016 & 0,1123 & NO & $52,30 \%$ \\
\hline OVER & 0,0012 & 0,0807 & YES & $52,36 \%$ \\
\hline FSIZE & 0,0001 & 0,0056 & BIG & $58,93 \%$ \\
\hline OP & 0,0000 & 0,0005 & YES & $59,68 \%$ \\
\hline $\mathrm{PF}$ & 0,0000 & 0,0002 & NO & $56,34 \%$ \\
\hline LA & 0,0000 & 0,0000 & YES & $62,18 \%$ \\
\hline
\end{tabular}

a.Mutual information: This is the amount of information given by a variable on the target value. b.Relative importance: The importance of this variable with respect to the target value.

a.Mutual information: This is the amount of information given by a variable on the targe
c.Modal value: The average value of the explanatory variable for each the target value. 
Table 5 shows that $90.01 \%$ of firm growth opportunities, $36.84 \%$ preference for internally generated resource, $85.43 \%$ of CEO optimism, $62.58 \%$ of CEO overconfidence non suggestibility . $53.58 \%$ of firm profitability and his size great to $62.22 \%$ implies that this company chooses to overinvestment with a probability of $12.2 \%$.

Target analysis suggested that $28.71 \%$ of CEO preference for the equity, $58.33 \%$ of firm of growth opportunity, $72.08 \%$ of CEO loss aversion, $53.59 \%$ of his overconfidence and a firm size large with $51.54 \%$ involve the presence of $12.11 \%$ of asset specificity.

$88.73 \%$ of CEO over-confidence, $26.33 \%$, preferably for the couple (internally generated resource+ debt ), $61.75 \%$ of his risk appetite, $66.39 \%$ of firm growth opportunities, $58.95 \%$ of CEO optimism bias non suggestibility and high firm size with $72.50 \%$ implies a CEO preference for overinvestment in long-term projects.

$36.16 \%$ CEO equity preference, $63.86 \%$ CEO optimism bias non suggestibility, firm low profitability to $67.54 \%, 69.45 \%$ of CEO loss aversion, $52.79 \%$ of overconfidence and a large firm size with probability of $55.05 \%$ implies a preference for investment projects in the short term with a probability of $11.14 \%$. $90.46 \%$ to firm growth opportunity, $27.93 \%$ preference for internally generated resource, $75.61 \%$ of CEO loss aversion, $71.34 \%$ of his optimism, a great firm size to $64.73 \%$, low profitability to $61.25 \%$ and $54.96 \%$ excess trust involves a preference for the under-investment with a probability of $54.96 \%$.

$24.96 \%$ of the CEO preference ( debt and equity), $74.62 \%$ of his loss aversion, $50.35 \%$ of lack firm future opportunities investment, $65.39 \%$ of leader over-confidence, a great firm size with a probability of $57.15 \%$ and low firm profitability of $60.98 \%$ kick start CEO to over-invest in specific investment and long term with a probability of $11.08 \%$. The presence of $88.69 \%$ firm growth opportunities, the $29.15 \%$ firm equity preference, $69.05 \%$ CEO over-confidence, $67.28 \%$ of his optimism and $51.15 \%$ of a low firm probability push the manager to choose the underinvestment and the short term with a probability of $9.40 \%$. Finally, the choice of $33.81 \%$ equity firm financing decision, the $52.30 \%$ lack of firm growth opportunities and $52.36 \%$ of CEO overconfidence push this leader to choose projects long-term investment with a probability of $52.36 \%$.

\subsection{Average target maximizing analysis}

After presenting all the explanatory variables for each category of the target variable, it is necessary to introduce the variables maximizing each modality of the target variable. Thus, the target dynamic profile capability software (Bayesialab) to query about an a posteriori maximization of the target average. This test shows the case to maximize the target variable value. Table 6 presents the dynamic profile of the investment decision (IND). The $100 \%$ decrease in the firm size and $18.5 \%$ increased the CEO preference of debt are correlated positively with the increase of the $12.11 \%$.specific investments. This result confirms the principle of independence between investment decision and financial reporting by corporate financial theory. The investment decision dynamic profile analysis (Table 6) presents the following findings:

The $37.76 \%$ increased use of internally generated resource, the $61.76 \%$ reduced level of growth opportunities and 75\% decreased CEO overconfidence level cause an increase of overinvestment with $12.20 \%$. This confirms our theoretical development and affirms the presence of a

negative correlation between CEO overconfidence and investment level. This executive overconfidence overestimates his skills to reduce firm risk. It tends therefore to invest more than a rational manager. The $26.15 \%$ increased preference of internally generated resource, $62.12 \%$ increasing the firm growth opportunities level and $100 \%$ decrease CEO overconfidence level are positively correlated with the increase under-investment of $11.14 \%$. 


\section{Table 6}

The Traget dynamic profile analysis

\begin{tabular}{|c|c|c|c|}
\hline \multicolumn{4}{|l|}{$\mathrm{IND}=\mathrm{AS}$} \\
\hline Nodes & Optimal modality & Probability & Joint probability \\
\hline A priori & & $12,11 \%$ & $100,00 \%$ \\
\hline $\mathrm{CSC}$ & LEV & $18,05 \%$ & $9,50 \%$ \\
\hline TAI & SMALL & $100,00 \%$ & $0,09 \%$ \\
\hline \multicolumn{4}{|c|}{ IND = OVERINV } \\
\hline Nodes & Optimal modality & Probability & Joint probability \\
\hline A priori & & $12,20 \%$ & $100,00 \%$ \\
\hline $\mathrm{CSC}$ & $\mathrm{CF}$ & $37,76 \%$ & $11,90 \%$ \\
\hline FIO & NO & $61,76 \%$ & $6,89 \%$ \\
\hline OVER & $\mathrm{NO}$ & $75,00 \%$ & $5,67 \%$ \\
\hline \multicolumn{4}{|c|}{$\mathrm{IND}=\mathrm{UNDINV}$} \\
\hline Nodes & Optimal modality & Probability & Joint probability \\
\hline A priori & & $11,14 \%$ & $100,00 \%$ \\
\hline $\mathrm{CSC}$ & $\mathrm{CF}$ & $26,15 \%$ & $11,90 \%$ \\
\hline FIO & YES & $62,12 \%$ & $5,01 \%$ \\
\hline OVER & $\mathrm{NO}$ & $100,00 \%$ & $2,87 \%$ \\
\hline \multicolumn{4}{|l|}{$\mathrm{IND}=\mathrm{LT}$} \\
\hline Nodes & Optimal modality & Probability & Joint probability \\
\hline A priori & & $7,48 \%$ & $100,00 \%$ \\
\hline $\mathrm{CSC}$ & LEV+EQ & $13,25 \%$ & $11,04 \%$ \\
\hline FIO & NO & $29,14 \%$ & $4,64 \%$ \\
\hline OVER & $\mathrm{NO}$ & $56,25 \%$ & $2,13 \%$ \\
\hline FSIZE & MEDIUM & $79,61 \%$ & $0,85 \%$ \\
\hline $\mathrm{PF}$ & YES & $100,00 \%$ & $0,56 \%$ \\
\hline \multicolumn{4}{|l|}{$\mathrm{IND}=\mathrm{ST}$} \\
\hline Nodes & Optimal modality & Probability & Joint probability \\
\hline A priori & & $11,14 \%$ & $100,00 \%$ \\
\hline $\mathrm{CSC}$ & $\mathrm{CF}+\mathrm{LEV}+\mathrm{EQ}$ & $22,53 \%$ & $17,36 \%$ \\
\hline OVER & $\mathrm{NO}$ & $73,23 \%$ & $2,19 \%$ \\
\hline FIO & YES & $100,00 \%$ & $1,53 \%$ \\
\hline \multicolumn{4}{|c|}{ IND $=$ LT+OVERINV } \\
\hline Nodes & Optimal modality & Probability & Joint probability \\
\hline A priori & & $11,24 \%$ & $100,00 \%$ \\
\hline $\mathrm{CSC}$ & $\mathrm{CF}+\mathrm{EQ}$ & $23,85 \%$ & $8,87 \%$ \\
\hline OVER & YES & $36,39 \%$ & $5,47 \%$ \\
\hline OP & $\mathrm{NO}$ & $52,16 \%$ & $3,57 \%$ \\
\hline OVER & YES & $68,66 \%$ & $1,95 \%$ \\
\hline LA & YES & $100,00 \%$ & $1,27 \%$ \\
\hline \multicolumn{4}{|c|}{$\mathrm{IND}=\mathrm{ST}+\mathrm{UNDINV}$} \\
\hline Nodes & Optimal modality & Probability & Joint probability \\
\hline A priori & & $9,40 \%$ & $100,00 \%$ \\
\hline FIO & YES & $14,88 \%$ & $56,00 \%$ \\
\hline $\mathrm{CSC}$ & $\mathrm{CF}+\mathrm{LEV}$ & $21,44 \%$ & $9,71 \%$ \\
\hline OVER & NO & $28,61 \%$ & $2,69 \%$ \\
\hline LA & NO & $50,00 \%$ & $1,54 \%$ \\
\hline \multicolumn{4}{|c|}{$\mathrm{IND}=\mathrm{AS}+\mathrm{LT}+\mathrm{OVERINV}$} \\
\hline Nodes & Optimal modality & Probability & Joint probability \\
\hline A priori & & $11,08 \%$ & $100,00 \%$ \\
\hline CSC & LEV+EQ & $25,05 \%$ & $11,04 \%$ \\
\hline LA & YES & $41,12 \%$ & $6,33 \%$ \\
\hline FIO & YES & $69,82 \%$ & $3,58 \%$ \\
\hline OVER & YES & $100,00 \%$ & $1,87 \%$ \\
\hline \multicolumn{4}{|c|}{$\mathrm{IND}=\mathrm{AS}+\mathrm{LT}+\mathrm{UNDINV}$} \\
\hline Nodes & Optimal modality & Probability & Joint probability \\
\hline A priori & & $14,21 \%$ & $100,00 \%$ \\
\hline $\mathrm{CSC}$ & LEV & $22,42 \%$ & $9,50 \%$ \\
\hline OVER & YES & $50,05 \%$ & $4,13 \%$ \\
\hline FIO & YES & $100,00 \%$ & $2,06 \%$ \\
\hline
\end{tabular}

Note.

a.Optimal modality: modality is maximizing the traget value .

b.Probability: the prior probability of each variable.

c. Joint probability: the probability that the target variable takes the value $\mathrm{n}$ given that the explanatory variable takes the value $\mathrm{p}$. for example, the probability of choosing AS+LT+UNDINV by an executive overconfidence is $4.13 \%$. 
Leader's overconfidence tends to overestimate the value of their project. They are reluctant to increase their capital by considering that the market systematically evaluates the value of securities. They give up the implementation of certain projects requiring recourse to external financing methods. This implies the presence of the under-investment situation.

The 13.25\% increased use of torque (debt and equity), 29.14\%lower growth opportunities, the $56.25 \%$ reduced CEO overconfidence level, $79.61 \%$ reduced to an average firm size and $100 \%$ increasing the firm profitability represents an increase in choice of long-term investment projects of around $7.48 \%$. This result contradicts our theoretical development. The leader overconfidence growth opportunity for his company seeks to ensure its status as the leader. It uses its leverage decision to minimize agency conflicts and ensure value creation. He chose short-term investments enhancing the value of his business.

The $22.53 \%$ increase in the use of all financial resources (internally generated resource, debt and equity), the $73.23 \%$ decrease in the CEO overconfidence level and $100 \%$ higher firm growth opportunities pushing Tunisian leader to increase its preference for investment projects in the short term of around $11.14 \%$. This finding contradicts our theoretical prediction. This is explained by the fact that overconfidence leaders who hold a large proportion of shares in the company they work for, have an expected utility of wealth is significantly affected by the variance of the anticipated firm benefits. So they tend to choose long-term investments valuing risky business.

The $23.85 \%$ increased preference for the couple (internally generates resource and equity), $36.39 \%$ increasing CEO overconfidence, the 52.16\% decrease CEO optimism level, $68.66 \%$ increased opportunities growth and $100 \%$ increased the CEO loss aversion level lead to increased preferences for over-investment manager and investment horizon length of about 11.24. The $14.88 \%$ increase firm growth opportunities, $21.44 \%$ higher preferences for the couple (debt and internally generated resource), the $28.61 \%$ decrease in the CEO overconfidence level and its loss aversion level of $50 \%$ implies an increase in preference for under-investment and short-term projects. The $25.05 \%$ increased preference for directing the couple enjoyed debt and equity, $41.12 \%$ increasing CEO loss aversion level, 69.82\% firm growth opportunities and 100\% increased managerial overconfidence level generate a increase in choice of specific investments and longterm over-investment of $11.08 \%$. Finally, $22.42 \%$ the increase in firm debt rate, $50.05 \%$ increasing CEO overconfidence level and 100\% increased firm growth opportunities to reflect $14.21 \%$ increase in the specific investments level and long-term underinvestment.

\section{Conclusion}

This research examines the determinants of firms' investment decision introducing a behavioral perspective. Theoretical analysis presented CEO emotional biases highlights role (optimism, loss aversion, overconfidence) to explaining his investment decision. Thus, the optimism of the leader over the problem of managerial opportunism described by the agency theory in specific projects. The leader optimistic about its firm growth opportunities level uses specific investments risky to reduce the risk of takeover and preserve its place at the head of his company. Behavioral investment level analysis has enriched the predictions of theories based on asymmetric information (signals theory and rooting theory) and agency theory in choice of underinvestment or overinvestment.

Empirical analysis presenting survey CEO large private companies in Tunisia. Data analyses revealed CEO emotional biases importance in explaining his investment decision. Indeed, empirical relationship analysis between optimism and investment decision shows behavioral dimension role in the explanation. CEO optimism level is positively correlated with a preference for specific investment and overinvestment level. An optimistic leader who seeks the benefit for him and his firm has an incentive to overinvest in specific investment. 
We also note that CEO loss aversion level is positively correlated with firm investment specific level and negatively correlated with overinvestment level. CEO loss aversion causes overestimate firm risk level, are more uncertain about forecasts and opt for making it safer to limit the likelihood of his removal. It uses specific investment and prefers under-investment in the case of firm low financing capacity. CEO overconfidence positively affects firm specific investment level and his overinvestment rate. Leader's overconfidence of their personal and professional capacities tends to make investments in research and development.

Thus, the existence of overconfidence leaders can destroy investment decisions either underinvestment or overinvestment. Finally, CEO investment decisions analysis by integrating the behavioral dimension is consistent with the corporate financial theory (agency theory, transaction cost and consolidation), the leader affected by behavioral biases (optimism, loss aversion, and overconfidence) adjusts its investment choices based on their ability to assess alternatives (optimism and overconfidence) and risk perception (loss aversion) to create of shareholder value and ensure its place at the head of the management team.

\section{References}

Albouy M., \& Schatt A. (2010). La politique de dividende permet-elle de discipliner les dirigeants ?, LEG UMR Cnrs 5118 - FARGO, Centre de recherche en Finance, Architecture et Gouvernance des Organisations, Cahier du FARGO n 1100603 , Juin 2010.

Baker M., Ruback, R.S., \& Wurgler J. (2004). Behavioral Corporate Finance: A Survey. SSRN, à paraître (2005) in B. Eckbo (Ed.), Handbook of Corporate Finance: Empirical Corporate Finance. SSRN_ID740946.

Baker, M, Richard S. R, \& Wurgler, J. (2007). Behavioral Corporate Finance. The Handbook of Corporate Finance, 1, 145-186

Barberis N., \& Thaler R. (2002). A Survey of Behavioral Finance. In forthcoming Handbook of the Economics of Finance, 1, 1053-1128.

Ben Kraiem, R. (2008). The influence of institutional investors on opportunistic earnings management, International Journal of Accounting Auditing and Performance Evaluation, 5 (1), 89-106.

Ben-David I., Graham J., \& Harvey C. (2006). Managerial Overconfidence and Corporate Policies, AFA 2007, Chicago Meetings Paper, http ://ssrn.com/abstract=890300.

Bertrand M., \& Mullainathan S. (2003). Enjoying the quiet life? Corporate governance and managerial preferences. Journal of Political Economy, 111 (5), 1043-1075.

Biais B., Hilton D., Mazurier K., \& Pouget S. (2005). Judgmental overconfidence, self- Monitoring, and trading performance in an experimental Financial Market. Review of Economic studies, 72 (25), 287-322.

Booth, L., Aivazian, V., Demirguc-Kunt, A., \& Maksimovic, V. (2001). Capital structure in developing Countries. Journal of Finance, 56, 87-130.

Bujadi, M.L., \& Richardson, A.J. (1997). A citation trail review of the uses of firm size in accounting research. Journal of Accounting literature, 16, 1-27.

Cazavan-Jeny, A. (2004). Le ratio market-to-book et la reconnaissance des immatériels- une étude du marché français. Comptabilité Contrôle Audit, 10 (2).

Chang, C., Lee, A.C., \& Lee, C.F. (2009). Determinants of capital structure choice : A structural equation modeling approach. The Quarterly Review of Economics and Finance, 49,197-213.

Cliche, A. (2000). Les déterminants de la gestion des risques par les entreprises non financières : une revue de la littérature. Cahier de recherche, 1206-3290.

Cockburn, I., \& Griliches, Z. (1988). Industry effects and appropriability measures in the stock market. American Economic Review, 78 (2), 419-424.

Demaria, S., \& Dufour, D. (2007). Les choix d'options comptables lors de la transition aux normes IAS/IFRS : quel rôle pour la prudence ?. Comptabilité-Contrôle- Audit, nº 195, 195-218. 
Draief, S. (2010). Structure Financière, Gestion Des Résultats Et Caractéristiques De La Firme. Comptabilité, contrôle, audit et institutions, halshs-00578113, version 1, 18 décembre.

Fama, E. F., \& French, K. R. (2002). Testing tradeoff and pecking order predictions about dividends and debt. Review of Financial Studies, 15, 1-33.

Felton, J., Gibson, B., \& Sanbonmatsu, D. (2003). Preference for Risk in Investing as a Function of Trait Optimism and Gender. The Journal of Behavioral Finance, 4(1), 33-40.

Gervais, S., Heaton, J.B., \& Odean, T. (2010). Overconfidence, compensation contracts, and capital budgeting. Journal of Finance, 3, 83-128.

Gervais, S., \& Odean, T. (2001). Learning to Be Overconfident. Review of Financial Studies, 14 (1), $1-27$.

Gervais, S., Heaton, J.B., \& Odean, T. (2002). The positive role of overconfidence and optimism in investment policy. Mimeo, University Of California, Berkeley.

Gibson B., and Sanbonmatsu D. (2004). The downside of optimism. Personality and Social Psychology, 30, (1), 149-160.

Goel A.M., \& Thakor A.V. (2000). Rationality Overconfidence and Leadership. Working Paper $n^{\circ}$ 00-022, University of Michigan Business School, 2000.

Graham, J., Campbell, H., \& Puri, M. (2009). Managerial Attitudes and Corporate Actions. Working Paper, Duke University, SSRN_ID1716966.

Griliches, Z. (1981). Market value, R\&D and patents. Economic Letters, 7(2), 183-187.

Gul, F.A., \& Tsui, J.S.L. (1998). A test of the free cash flow and debt monitoring hypotheses : Evidence from audit pricing. Journal of Accounting and Economics, 24, 219-237.

Hackbarth, D. (2009). Determinants of corporate borrowing: A behavioral perspective. Journal of Corporate Finance, 15, 389-411.

Hawkins S.A., Hoch, S.J., \& Meyers-Levy, J. (2001). Low-involvement learning: Repetition and coherence in familiarity and belief. Journal of Consumer Psychology, 11, 1-11.

Heaton, J. (2002). Managerial optimism and corporate finance. Financial Management, 31, 33-45.

Helliar, C., Power, D., \& Sinclair, C. (2005). Managerial "irrationality" in financial decision making. Managerial Finance, 31 (4), 1-11.

Ho, C.R., \& Chang, Y. (2009). CEO Overconfidence and Corporate Financial Distress , August 15, 2009, Electronic copy available at: http://ssrn.com/abstract $=1659440$.

Hovakimian, A., Hovakimian, G., \& Tehranian, H. (2004). Determinants of target capital structure: The case of dual debt and equity issues. Journal of Financial Economics, 71, 517-540.

Jaggi, B., \& Gul, F.A. (1999). An analysis of joint effects of investment opportunity set, free cash flows and size on corporate debt policy. Review of Quantitative Finance and Accounting, 12(4), 371-381.

Jarboui, A., \& Olivero, B. (2008). Le couple Risque/ Horizon temporel des investissements est-il gouverné par les institutionnels et les actionnaires dominants ?, Banque et Marchés, $n^{\circ}$ 93, MarsAvril, 20-34.

Jensen, M.C. (1986). Agency costs of free cash-flow, corporate finance and takeovers. American Economic Review, 76, 323-339.

Koh, P.S. (2003). On the association between institutional ownership and aggressive corporate earnings management in Australia. The British Accounting Review, 35, 105-128.

Lang, L., Stulz, R.M., \& Walkling R.A. (1991). a test of free cash-flow hypothesis the cash of bidder return. Journal of Financial Economics, 29, 315-335.

Lehn, K., \& Poulsen, A.B. (1989). Free Cash Flow and Stockholder Gains in Going Private Transactions. Journal of Finance, 44, 771-787.

Lin Y.H., Hu, S.Y., \& Chen, M.S. (2007). Testing Peking order prediction from the viewpoint of managerial optimism: Some empirical evidence from Taiwan. Pacific-Basin Finance Journal, 16, 160-181.

Lin, Y., Hu, S. \& Chen, M. (2005). Managerial optimism and corporate investment: Some empirical evidence from Taiwan. Pacific-Basin Finance Journal, 13(5), 523-546. 
Lindenberg, E., \& Ross S. (1981). Tobin's q ratio and industrial organization. Journal of Business, 54 (1), 1-32.

Mairesse, J., \& Mohnem, P. (2005). The importance of R\&D for Innovation: A reassessment using French survey data. The Journal of Technology Transfer. 30, 183-197.

Malmendier, U., \& Tate, G. (2005). CEO overconfidence and corporate investment. Journal of Finance, 60(6), 2661-2700.

Malmendier, U., \& Tate, G. (2008). Who makes acquisitions?, CEO overconfidence and the market's reaction. Journal of Financial Economics, 89, 20-43.

Malmendier, U., Tate, G., \& Yan, J. (2010). Managerial beliefs and corporate financial policies. Working Paper $\mathrm{n}^{\circ} 105$, UC Berkeley and UC Los Angeles, Faculty.fuqua.duke.edu.

Maslow A. (1989). Vers une psychologie de l'être . Fayard, Paris, 1989.

Megna, P., and Klock, L. (1993). The impact of intangible capital on Tobin's Q in the semiconductor industry. American Economic Review, 265-269.

Molay E. (2006). Un test de la théorie de financement hiérarchique sur données de panel françaises, document de travail, université de Nice IAE, pp. 1- 24.

Moussu C., \& Thibierge C. (1997). Politique financière, opportunité d'investissement et actifs immatériels en Europe : théorie et étude empirique. Banque et marchés n³0, septembre- octobre, 6-21.

Myers, S.C. (2001). Capital structure. Journal of Economic Perspectives, 15, 81-102.

Naoui K., Elgaied M., \& Bayoudh F. (2008). Financement Interne et Investissement : Asymétrie d'Information vs Discrétion Managériale. http://ssrn.com/abstract=1118416.

Nosic A., \& Weber M. (2008). How risky do I invest: The role of risk attitudes, risk perceptions and overconfidence. Decision Analysis, 7, 282-301.

Pearl J. (1986). Fusion, propagation, and structuring in belief networks. Journal of Artificial Intelligence, 29, 241,288,

Rajan R., \& Zingales L. (1998). Power in a theory of the firm. Quarterly Journal of Economics, 133 (2), 387-432.

Roll, R. (1986), The hubris hypothesis of corporate takeovers. Journal of Business, 59, 197-216.

Sahut J.M., \& Gharbi O. (2008). Investisseurs institutionnels et valeur de la firme, papier de travail, Université de Poitiers et Université Paul Cézanne hal-00645361, 1-28.

Sautner, Z., \& Weber, M. (2009). How Do managers behave in stock option plans? Clinical evidence from exercise and survey data. Journal of Financial Research, 32, 123-155.

Schrand, C., \& Zechman, S. (2010). Executive Overconfidence and the Slippery Slope to Fraud, Working Paper, University of Chicago.

Simon, M., \& Houghton, S.M. (2003). The relationship between overconfidence and the introduction of risky products: Evidence from a field study. Academy of Management Journal, 46,139-149.

Skinner, D. (1993). The investment opportunity set and accounting procedure choice: Preliminary evidence. Journal of Accounting and Economics, 16 (4), 407 - 445.

Thibierge, C. (2001). Actifs immatériels, valorisation boursière et contrainte d'endettement : étude empirique sur les marchés français et espagnol. Congrès international de l'Association Française de Finance, Namur, 28-30, http://www.fundp.ac.be/eco/affi2001/main.html.

Titman, S. (1984). The effect of capital Structure on a firm's liquidation decision. Journal of Financial Economics, 13, 137-151.

Wang, T. (2006). Real investment and corporate securities fraud. Working paper, University of Minnesota. 